\title{
Manajemen Pembelajaran Sekolah Terpadu (Studi Pada Sekolah Terpadu Al Biruni Makassar)
}

\author{
Sumarlin Mus ${ }^{1}$, Syamsurijal Basri ${ }^{2}$ \\ 1,2 Program Studi Administrasi Pendidikan Fakultas Ilmu Pendidikan Universitas Negeri Makassar \\ ${ }^{1}$ sumarlin.mus@gmail.com \\ 2srijal.manj@gmail.com
}

\begin{abstract}
This study reviews the learning management integrated school in Makassar with research sites in an integrated school Al Biruni Makassar. The focus in this research is the learning management in an integrated school which consists of lesson plans, learning implementation, and evaluation. The approach used in this study is a qualitative descriptive approach. The unit of analysis in this research is the principal, teachers, and students. Data collection techniques were interviews, observation, and documentation. The results showed that the learning management consisting of lesson plans, learning implementation, and evaluation of learning has been implemented in accordance with the existing procedures as other schools in general. This integrated concept in this school that is located in its curriculum, which integrates religious values on each of the subjects taught to students.
\end{abstract}

Keywords: Learning Management, Integrated School

\section{PENDAHULUAN}

Manajemen pembelajaran dipandang sebagai suatu cara yang dapat membantu para guru dalam melaksanakan tugas dan tanggung jawabnya sebagai pengelola pendidikan dan pengajaran di sekolah, tanpa hal tersebut tidak mungkin proses belajar mengajar dapat berjalan secara efektif dan efesien serta mencapai hasil yang maksimal.

Kondisi objektif mengenai pembelajaran secara umum disekolah-sekolah menunjukkan bahwa banyak para guru kurang memahami konsep manajemen pembelajaran. Contoh konkritnya yaitu kebanyakan guru tidak mampu menyusun rancangan program pembelajaran dan hanya menjiplak dari berbagai buku atau internet, sehingga materi yang diajarkan tidak sesuai dengan tujuan dan kebutuhan siswa. Pada pelaksanaan pembelajaran kebanyakan guru hanya menggunakan metode ceramah dan penggunaan media pembelajaran sangat kurang. Sedangkan tahap evaluasi pembelajaran, ratarata guru hanya menggunakan satu unsur evaluasi dalam pembelajaran.

Kegiatan pembelajaran di setiap satuan pendidikan berbeda-beda, baik itu di sekolah negeri maupun sekolah swasta. Salah satu sekolah yang menarik peneliti untuk meneliti secara mendalam yaitu model sekolah terpadu. Konsep sekolah terpadu merupakan salah satu praktek manajemen sekolah yang menerapkan efektivitas dan efesiensi dalam pengelolaan. Salah satu contoh konkritnya yaitu setiap satuan pendidikan yang berada dibawah naungan yayasan berada dalam satu kompleks yang di koordinir oleh satu orang, guru yang mengajar diharapkan mampu dan bisa mengajar di setiap satuan pendidikan yang berbeda sehingga kekurangan tenaga pengajar dapat diatasi. Dengan contoh dan fenomena diatas jika diamati secara sepintas manajemen pembelajaran di sekolah dapat terganggu atau tidak berjalan secara maksimal

Setiap organisasi, baik itu organisasi besar atau kecil, maupun organisasi publik atau privat, tentu membutuhkan pengelolaan organisasi yang disebut manajemen untuk mengatur dan memberdayakan segala sumber daya yang ada dalam organisasi secara maksimal agar pencapaian tujuan secara efektif dan efesian dapat diwujudkan.

Menurut Terry (1977:4) "management is distinct consisting of planning, organizing, actuating, controlling utilizing in each both science and art and follow in order to accomplish predetermined objective." Dari kutipan tersebut, manajemen dapat diartikan sebagai suatu kegiatan yang mencakup perencanaan, pengorganisasian, pengarahan, dan pengendalian sumber daya dengan menggunakan ilmu dan seni untuk mencapai 
sasaran. Pengertian yang hampir sama dikemukakan Steers, et al. (dalam Terry.1977:5) yang mendefinisikan manajemen sebagai berikut:

Management is the process of planning, organizing, directing, and controlling the activities of employees in combination with other organizational resources to accomplish stated organizational goals. Underlying this definition are the assumptions that organizational goals is helped greatly by coordinating various work activities, and that a central figares are needed to ensure that the parts of a group or organization work together.

Menurut kutipan tersebut dapat ditarik kesimpulan bahwa manajemen merupakan suatu proses perencanaan, pengorganisasian, pengarahan, dan pengawasan atau pengendalian terhadap aktivitas sumber daya manusia yang dikombinasikan dengan sumber daya lain dalam organisasi untuk mencapai tujuan organisasi. Tujuan organisasi dapat dicapai apabila terdapat koordinasi diantara aktivitas yang bervariasi.

Sedangkan dalam pengertian manajemen tersebut terdapat empat fungsi manajemen pokok yaitu perencanaan, pengorganisasian, pengarahan, dan pengawasan atau pengendalian. Keempat fungsi manajemen tersebut dikemukakan Steers, et al. (dalam Terry.1977) sebagai berikut.

1. Planning. To make the best possible use of an organication's scarce resources, managers must engage in variety of planning activities.

2. Organizing. Managers must bring together individuals and tasks to make effective use of people and resources.

3. Directing. A manager must be able to make employees want to participate actively in achieving an organization's goals.

4. Controlling. Control systems can be found throughout organizations

Sekolah merupakan organisasi sosial yang menyediakan layanan pembelajaran bagi masyarakat. Sebagai organisasi, sekolah merupakan sistem terbuka karena mempunyai hubungan-hubungan dengan lingkungan. Selain sebagai wahana pembelajaran, lingkungan juga merupakan tempat berasalnya masukan sekolah yang meliputi manusia (man), uang (money), benda-benda (materials), metode-metode (methods) dan mesin-mesin (machines). Tugas pokok seorang manajer ialah menggerakkan serta mengkoordinir orang-orang, alat-alat, bahan, uang, metode, mesin-mesin, dan lain-lain untuk mencapai tujuan yang dikehendaki atau dengan kata lain bahwa berperannya fungsi-fungsi manajemen dengan baik akan menghasilkan koordinasi yang baik pula.

Para ahli manajemen mengemukakan pendapat yang berbeda tentang fungsi manajemen. Diantaranya adalah Terry (dalam Winardi, 2000) menyatakan bahwa fungsifungsi manajemen meliputi:(1)planning (perencanan),(2)organizing (pengorganisasian),

(3) actuating (penggerakan), dan (4) controlling (pengawasan).

Gulick (dalam Winardi, 2000) mengemukakan bahwa dalam manajemen terkandung 7 fungsi yaitu: planning,(2)organizing,(3) Staffing, directing, (5) coordinating, (6) reporting, dan (7) budgeting. Fayol (dalam Winardi, 2000) mengemukakan fungsi manajemen sebagai berikut:(1) planning (2) organizing, (3) command, (4) cordination, dan (5) controling.Sedangkan Hick (dalam Winardi, 2000) fungsi manajemen sebagai berikut: (1) planning, (2) organizing, (3) motivating,(4) communication, (5) controlling, dan (6) creating. Anderson (dalam Winardi, 2000) membagi manajemen dalam 5 elemen sebagai berikut:(1) planning, (2) organizing, (3) staffing, (4) excecuting, dan (5) appraising.

Pendapat para ahli di atas memiliki kesamaan pada tiga fungsi manajemen yaitu perencanaan, pengorganisasian, dan pengawasan. Sedangkan fungsi manajemen lain seperti: staffing (pengadaan tenaga), directing (pemberian bimbingan), coordinating (pengkoordinasian), commanding (pemberian komando) tidak digunakan Terry, tetapi mempergunakan istilah actuating (menggerakkan) sebagai fungsi yang menunjukkan proses penggerakan bawahan untuk mendapatkan hasil yang diinginkan. Istilah ini jauh lebih lunak dibandingkan dengan istilah lain yang sama maksudnya

Mengajar di sekolah adalah pekerjaan yang memerlukan keahlian khusus. Sebagai kegiatan yang berkaitan dengan pembinaaan potensi anak yang jarang mengalami perkembangan, seorang guru harus benar ahli dalam tugasnya. Guru adalah sebagai manajer di dalam organisasi kelas. Sebagai seorang manajer, aktivitas guru mencakup kegiatan merencanakan, mengorganisir, memimpin, dan mengevaluasi hasil kegiatan belajar mengajar yang dikelolanya. Tugas professional guru adalah melakukan kegiatan mengajar, dan selanjutnya murid memberikan respon-respon 
yang disebut belajar. Interaksi kedua kegiatan tersebut yaitu mengajar dan belajar di dalam kelas di sebut proses pembelajaran

Menurut Sagala (2005:61) pembelajaran adalah "membelajarkan siswa menggunakan asas pendidikan maupun teori belajar merupakan penentu utama keberhasilan pendidikan"

Jarangkan Menurut Dimyati dan Mudjiono (Sagala 2005:62) pembelajaran adalah "kegiatan guru secara terprogram dalam desain instruksional, untuk membuat siswa belajar secara aktif, yang menekankan pada penyediaan sumber belajar". Sebagaimana tercamtum dalam Undang-undang No. 20 tahun 2003 tentang sistem pendidikan nasional menyatakan bahwa pembelajaran adalah proses interaksi peserta didik dengan pendidik dan sumber belajar pada lingkungan belajar.

Dari beberapa defenisi di atas, dapat disimpulkan bahwa pembelajaran adalah setiap kegiatan yang dirancang oleh guru untuk membantu seseorang mempelajari suatu kemampuan dan atau nilai yang baru dalam suatu proses yang sistematis melaui tahap rancangan, pelaksanaan dan evaluasi dalam konteks kegiatan belajar mengajar.

Salah satu sekolah di Makassar dengan model manajemen yang terpadu yaitu sekolah terpadu Al Biruni Makassar. Dari gambaran di atas tentang konsep sekolah terpadu yang berdampak pada manajamen pembelajaran di sekolah, maka peneliti tertarik untuk meneliti pelaksanaan manajemen pembelajaran dengan konsep sekolah terpadu.

\section{METODE PENELITIAN}

Jenis penelitian ini adalah penelitian deskriptif kualitatif, metode deskriptif kualitatif dimaksudkan menggambarkan atau mendeskripsikan data-data factual yang diperoleh melalui penerapan manajemen pembelajaran di sekolah islam terpadu AlBiruni Makassar. Cakupan fokus penelitian ini meliputi perencanaan pembelajaran, pelaksanaan pembelajaran, evaluasi pembelajaran di sekolah islam terpadu AlBiruni makassar.

Deskripsi fokus penelitian yang dapat diuraikan sebagai berikut:

1. Perencanaan pembelajaran adalah kegiatan guru dalam menyusun silabus dan rencana program pembelajaran.

2. Pelaksanaan pembelajaran adalah kegiatan guru dalam membuka pelajaran, menyampaikan materi pelajaran, penggunaan metode pelajaran, penggunaan media/alat peraga pendidikan, pengelolaan kelas, dan menutup pelajaran.

3. Evaluasi pembelajaran adalah kegiatan guru dalam Penggunaan alat evaluasi, Laporan hasil evaluasi, serta perbaikan/pengayaan.

Sumber data adalah kepala sekolah, guru, orang tua siswa dan siswa. Sesuai dengan jenis penelitian maka yang menjadi instrument penelitian adalah peneliti sendiri yang akan turun ke lapangan secara langsung untuk mendapatkan data penelitian dengan teknik atau cara mengumpulkan data yang terdiri dari wawancara, observasi, dokumentasi

Teknik analisis data dalam penelitian ini adalah analisis data kualitatif yang dilakukan dengan interaktif model, Aktivitas tersebut adalah reduksi data (data reduction), penyajian data (data display) dan coclusion drawing/verification (Sugiyono, 2013:234).

\section{HASIL \& PEMBAHASAN}

Secara umum, penelitian ini mengkaji manajamen pembelajaran dalam tiga aspek yaitu perencanaan pembelajaran, pelaksanaan pembelajaran, dan evaluasi pembelajaran. Berdasarkan hasil wawancara dan dokumentasi peneliti maka dapat disimpulkan bahwa perencanaan pembelajaran di Sekolah Islam Terpadu Al Biruni Makassar telah sesuai dengan mekanisme yang ada pada umummnya, akan tetapi terjadi sedikit perubahan pada RPP yang telah disusun dengan memasukkan atau memadukan unsur-unsur keagaamaan dalam RPP yang telah mereka susun.

Pelaksanaan pembelajaran dapat disimpulkan bahwa Sekolah Islam Terpadu Al Biruni Makassar telah melakukan konsep fullday school dalam pembelajaran dengan melakukan pembelajaran indoor dan outdoor sebagai pengembangan teori yang didapat di kelas kemudian diaplikasikan di luar kelas/sekolah. Unsur dalam pembelajaran yang sangat mereka perhatikan adalah penggunaan metode pembelajaran yang harus variatif karena dalam penyampaian materi pembelajaran guru harus dituntut untuk mengintegrasikan nilai-nilai agama/spritual pada setiap pelajaran yang diajarkan.

Evaluasi hasil belajar siswa yang dilakukan oleh guru kepada siswa tetap mengacu kepada penilaian kognitif, afektif, dan psikomotor dengan teknik penilaian berupa tes tulis, lisan, dan praktek. Hasil ini juga sejalan dengan observasi dan dokumentasi peneliti yang menunjukkan bahwa guru telah melakukan evaluasi sesuai dengan yang ada dalam RPP 
yang telah disusun pada perencanaan pembelajaran.

Pada kegiatan merencanakan pembelajaran, pendidik menentukan tujuan pembelajaran, yakni tujuan yang ingin dicapai setelah terjadinya proses-kegiatan pembelajaran. Pembelajaran merupakan suatu proses yang terdiri dari aspek, yaitu apa yang dilakukan peserta didik dan apa yang dilakukan pendidik. Oleh karena itulah, untuk mendapatkan proses pembelajaran yang berkualitas dan maksimal, maka dibutuhkan adanya perencanaan.Perencanaan pembelajaran adalah proses pengambilan keputusan berdasarkan hasil berpikir secara rasional, tentang sasaran dan tujuan pembelajaran tertentu perubahan tingkah laku peserta didik setelah melalui pembelajaranserta upaya yang harus dilakukan dalam mencapai tujuan tersebut. Konkretnya, dalam perencanaan pembelajaran ini pendidik membuat perangkat pembelajaran.di Sekolah Islam Terpadu Al Biruni Makassar telah sesuai dengan mekanisme yang ada pada sekolah pada umummnya, akan tetapi terjadi sedikit perubahan pada RPP yang telah disusun dengan memasukkan atau memadukan unsurunsur keagaamaan dalam RPP yang telah mereka susun

Pelaksanaan pembelajaran adalah interaksi guru dan siswa dalam rangka menyampaikan bahan pelajaran kepada siswa dan untuk mencapai tujuan pembelajaran. Dari definisi tersebut diketahui bahwa dalam proses pembelajaran terdapat beberapa unsur diantaranya adalah pembelajaran sebagai sebuah proses yang bertujuan untuk membelajarkan siswa di dalam kelas. Dalam kegiatan pembelajaran terjadi proses interaksi yang bersifat edukatif antara guru dengan siswa. Kegiatan yang dilaksanakan tersebut bermuara pada satu tujuan yaitu untuk mencapai tujuan pembelajaran yang telah ditetapkan sebelumnya

Pada kegiatan pelaksanaan pembelajaran, pendidik mengumpulkan dan menyatukan berbagai macam sumber daya dalam proses pembelajaran; baik pendidik, peserta didik, ilmu pengetahuan serta media belajar. Dan dalam waktu yang sama, mensinergikan antara berbagai sumberdaya yang ada dengan tujuan yang akan dicapai. Di Sekolah Islam Terpadu Al Biruni Makassar telah melakukan konsep fullday school dalam pembelajaran dengan melakukan pembelajaran indoor dan outdoor sebagai pengembangan teori yang didapat di kelas kemudian diaplikasikan di luar kelas/sekolah. Unsur dalam pembelajaran yang sangat mereka perhatikan adalah penggunaan metode pembelajaran yang harus variatif karena dalam penyampaian materi pembelajaran guru harus dituntut untuk mengintegrasikan nilai-nilai agama/spritual pada setiap pelajaran yang diajarkan

Pada kegiatan mengevaluasi pembelajaran, pendidik melakukan penilaian (evaluasi) terhadap pembelajaran yang telah berlangsung. Dalam kegiatan menilai itu pendidik dapat menemukan bagaimana proses berlangsungnya pembelajaran serta sejauh mana tujuan pembelajaran dapat tercapai. Sehingga kemudian dapat menemukan berbagai upaya untuk meningkatkan kualitas pembelajaran berikutnya. Melalui kegiatan mengevaluasi pembelajaran ini kemudian dapat dilakukan upaya perbaikan pembelajaran. Di Sekolah Islam Terpadu Al Biruni Makassar evaluasi hasil belajar siswa yang dilakukan oleh guru kepada siswa tetap mengacu kepada penilaian kognitif, afektif, dan psikomotor dengan teknik penilaian berupa tes tulis, lisan, dan praktek. Hasil ini juga sejalan dengan observasi dan dokumentasi peneliti yang menunjukkan bahwa guru telah melakukan evaluasi sesuai dengan yang ada dalam RPP yang telah disusun pada perencanaan pembelajaran

\section{KESIMPULAN \& SARAN}

Berdasarkan hasil penelitian dan pembahasan menunjukkan bahwa manajemen pembelajaran yang terdiri dari perencanaan pembelajaran, pelaksanaan pembelajaran, dan evaluasi pembelajaran telah dilaksanakan sesuai dengan prosedur yang ada seperti pada sekolah pada umumnya. Konsep terpadu pada sekolah ini yaitu terletak pada kurikulumnya, yang mengintegrasikan nilai-nilai keagamaan pada setiap mata pelajaran yang diajarkan kepada siswa.

\section{DAFTAR PUSTAKA}

Endang, S. 2000. Pengantar Teori Perencanaan Berdasrkan Pendekatan

Sistem. Yogyakarta: Adicipta Karya Nusa

Fattah Nanang. 2000. Landasan Manajemen Pendidikan. Bandung: Remaja Rosda Karya

Hasibuan, S.P Melayu. 1990. Manajemen Sumber Daya Manusia. Jakarta: Mas Agung

2001. Manajemen Dasar, Pengertian dan Masalah. Edisi Revisi. Jakarta: Bumi Aksara 
Hasibuan \& Moedjiono. 2006. Proses Belajar Mengajar. Jakarta: PT. Rineka Cipta.

Mahtika, Hanafie. 2007. Pengambilan Keputusan Statejik. Makassar: Badan Penerbit UNM.

Sagala, Syaiful. 2005. Konsep dan Makna Pembelajaran. Bandung: CV.Alfabeta

Sedarmayanti. 2001. Dasar-Dasar Pengetahuan Tentang Manajemen Perkantoran Suatu Pengantar. Edisi Revisi. Bandung: Mandar Maju

Siagian Sondang, P. 1977. Filsafat Administrasi. Jakarta: Gunung Agung

\begin{tabular}{ccc} 
Kepempinan & 1991. Organisasi \\
\hline dan & Perilaku
\end{tabular} Kepempinan dan Perilaku Adminiatrasi. Jakarta: Haji Mas Agung

2005. Fungsi-Fungsi

Manajerial. Edisi Revisi. Jakarta: Bumi Aksara

Sugiyono. 2013. Metode Penelitian Administrasi. Bandung: Alfabeta

Suyrosubroto. 2004. Manajemen Pendidikan di Sekolah. Jakarta: Rineka Cipta

Suryosubroto. 1997. Proses Belajar Mengajar di Sekolah. Jakarta: PT. Remaja Rosda Karya.

Terry, George R. 2000. Prinsif-Prinsif Manajemen. Alih Bahasa J. Smith D.F.M. Jakarta: Bumi Aksara

2003. Prinsif-Prinsif Manajemen (Edisi Bahasa Indonesia). Jakarta: Bumi Aksara

Undang-undang Sistem Pendidikan Nasional (UU. RI No. 20 Thn 2003). 2003. Jakarta: Sinar Grafika

Usman, Uzer. 2002. Menjadi Guru Profesional. Bandung: PT. Remaja Rosda Karya.

Winardi. 2000. Kepemimpinan Dalam Organisasi. Jakarta: Prenhallindo. 